\title{
下咽頭喉頭所見と逆流性食道炎との関連について
}

井上 斉, 山口 宏也*, 半井 英夫**
蔭原 聞 天**, 廣瀬 肇***

\section{The Laryngeal and Hypopharyngeal Findings and Sings Caused by Gastroesophageal Reflux Disease}

\author{
Hitoshi Inoue, M.D.," Hiroya Yamaguchi, M.D., ${ }^{*}$ Hideo Nakarai, M.D., ${ }^{* *}$ \\ Bunten Kagehara, M.D., ${ }^{* *}$ and Hajime Hirose, M.D. ${ }^{* * *}$ \\ * Department of Otorhinolaryngology and Department of Gastroenterology, \\ ** Tokyo Senbai Hospital, Tokyo, and ${ }^{* * *}$ Kitasato University \\ School of Medicine-Allied Health Sciences, Kanagawa
}

In the U.S. and Europe, reflux esophagitis has been considered to be an important cause of laryngeal disease based on the assumption that the reflux of stomach contents either directly or indirectly leads to an inflammation of larynx or vocal cord nodules. In the present study, esophagoscopy was performed on 20 patients who complained of abnormal sensation in the laryngopharyngeal region and who were found to have a pooling of saliva in the piriform sinus and redness of the arytenoid region or the vocal cords under indirect laryngoscopy. Evidence of esophageal inflammation was observed in half ( 10 cases) of the patients. All of the 20 cases were given advice on their life-style and were treated with a proton pump inhibitor. Improvements were obtained in 9 of the 10 cases esophagoscopically, and in 16 out of the 20 cases in terms of subjective symptoms. It was suggested that esophagoscopy shoud be performed for the purpose of a differential diagnosis for those patients who complain of an abnormal sensation in the laryngopharyngeal region and show positive findings in the hypopharynx or larynx, in consideration of the possibility of reflux esophagitis.

Key words : 逆流性食道炎, プロトンポンプ阻害剤, 咽喉頭異常感, 食道鏡, gastroesophageal reflux disease

\section{I 、はじめに}

逆流性食道炎は, 胃内容が食道へ逆流するこ とによって起こる食道粘膜の炎症ないし潰瘍病 変である。欧米ではこの逆流現象によって起こ る病態を, 粘膜病変の有無とは関係なく胃食道

*東京専売病院耳鼻咽喉科, **東京専売病院消化器内 科, $* * *$ 北里大学

別刷請求： 7108 東京都港区三田1-4-3 東京専売病院耳鼻咽喉科 井上 斉 投稿受付：1995年 3 月 24 日
逆流症 (gastro-esophageal reflux disease: GERD）と総称するのが一般的となってきてい る ${ }^{1)}$ 。また, 耳鼻咽喉科領域では逆流現象が直接 あるいは間接的に喉頭の慢性の炎症を引き起こ し，さらには声帯結節などの誘因になり得ると いう立場から，喉頭疾患の診断および治療に際 して逆流性食道炎の存在が重要視されている。 しかし，本邦では逆流性食道炎と喉頭疾患に関 する耳鼻咽喉科領域の文献は検索した限りでは 見当たらない。今回, 逆流性食道炎と下咽頭, 喉頭所見, 自覚症状との間にどのような関連が 
あるか, また治療によって下咽頭, 喉頭所見, 食道内視鏡所見がどのように変化するか検討を 行った。

\section{II . 対象および方法}

対象は1993年 9 月から1994年 8 月までの12力 月間に東京専売病院耳鼻咽喉科を受診した31歳 から73歳までの男性17例，女性 3 例の計 20 症例 で, 平均年齢は56歳であった。咽喉頭異常感あ るいは音声障害などを主訴として来院し, 喉頭 ファイバースコープにて下咽頭梨状窩の唾液貯 留, 披裂部の発赤, 声帯後方の発赤などを認め た症例に対し食道内視鏡検査を行った。

現在使用されている逆流性食道炎の分類は, (1) Savary \& Miller 分類，(2) AFP 分類，(3) 食 道疾患研究会による食道炎の診断基準などいろ いろな方法があるが, 今回の検討において使用 した逆流性食道炎の分類は，国際的にも広く用 いられている Savary \& Miller 分類をもとに, 自覚症状を認めるが食道内視鏡所見に異常を認 めないものを Stage 0 として追加した独自の基 準を使用した（表 1 )。

一般的に治療方針としては日常生活指導, 薬 物療法, 外科的治療と 3 段階に分けられるが, 今回われわれは生活指導としては食事指導を中 心に就富前の食事の摄取制限, 就寝時の上体の 挙上, 嗜好品の制限, 脂質や香辛料の制限など を行った(表 2 )。今回のこれらの生活指導は外 来診療中にのみ行った。

今回使用した薬剤は本邦で初めて開発された プロトンポンプ阻害剤であるランソプラゾール で, $30 \mathrm{mg}$ を 1 日 1 回朝食後に経口投与し, 投与 期間は 8 週間連続とした。、その後喉頭ファイバ ースコープ, 食道内視鏡検査を施行し内視鏡所 見, 下咽頭, 喉頭所見, および自覚症状の治療 前後の変化を比較検討した。同薬剤の投与期間 中は極力併用薬を避けるようにした。

\section{III. 結 果}

食道内視鏡所見は軽症例が主で，全症例中に は Stage 3, Stage 4 の重症例は認められず, Stage 0 が10例, Stage 1 が 5 例, Stage 2 が 5 例 であった。治療後 2 段階以上改善したものを著 明改善, 1 段階改善したものを改善, 変化のな
表 1 食道内視鏡所見による分類

\begin{tabular}{|c|c|}
\hline Stage 0 & $\begin{array}{l}\text { 内視鏡所見に異常がなく自覚症状を呈 } \\
\text { するもの。 }\end{array}$ \\
\hline Stage 1 & $\begin{array}{l}1 \text { 個あるいはそれ以上の非融合性の紅 } \\
\text { 斑を伴う粘膜病変あるいは表層性びら } \\
\text { んを伴うもの。 }\end{array}$ \\
\hline Stage 2 & $\begin{array}{l}\text { びらん性, 渗出性の融合した病変で, } \\
\text { 食道の全周囲を被っていないもの。 }\end{array}$ \\
\hline Stage 3 & $\begin{array}{l}\text { びらん性, 滲出性の病変が食道粘膜全 } \\
\text { 周を被っており, 狭窄を有しない壁の } \\
\text { 炎症性浸潤を起こしているもの。 }\end{array}$ \\
\hline \multirow[t]{2}{*}{ Stage 4} & $\begin{array}{l}\text { 慢性の粘膜病変を伴うもの（潰瘍, 壁 } \\
\text { の線維化, 狭窄, 短食道円柱上皮を伴 } \\
\text { う瘷痕化）。 }\end{array}$ \\
\hline & 表 2 生活指導 \\
\hline \multicolumn{2}{|c|}{ 1. 就寝前約 3 時間の食事摂取制限 } \\
\hline \multicolumn{2}{|c|}{ 2. 就誛時の上体の挙上 } \\
\hline \multicolumn{2}{|c|}{ 3. . アルコール・喫煙など喍好品の制限 } \\
\hline \multicolumn{2}{|c|}{$\begin{array}{l}\text { 4. チョコレート・カフェイン含有飲料・柑橘 } \\
\text { 類など酸分泌促進や粘膜刺激作用のある飲 } \\
\text { 食物の制限 }\end{array}$} \\
\hline \multicolumn{2}{|c|}{$\begin{array}{l}5 . \text {. 胃排出を遅延させる脂質や香辛料の制限 } \\
\text { 6. 過度の運動を避ける }\end{array}$} \\
\hline
\end{tabular}

表 3 総合的所見の変化

\begin{tabular}{|c|c|c|c|c|}
\hline & \multirow{2}{*}{ 治療前 } & \multicolumn{3}{|c|}{ 療 後 $\quad(\%)$} \\
\hline & & 著明改善 (\%) & 改 善(\%) & 変化なし(\%) \\
\hline Stage 0 & 10例 & 0 例 ( 0 ) & 7 例 (70) & 3 例 (30) \\
\hline Stage 1 & 5 例 & 2 例 (40) & 2 例 (40) & 1 例 (20) \\
\hline Stage 2 & 5 例 & 2 例 (40) & 3 例 (60) & 0 例 ( 0 ) \\
\hline
\end{tabular}

いものを変化なしとした。総合評価では著明改 善が 4 例, 改善が12例, 変化なしが 4 例であっ た。治療後症状が悪化した症例は認められなか った。Stage 0 の10例中 7 例は自覚症状の改善 を認め症状が消失し， 3 例は変化なしと判定し た。Stage 1 の 5 例中 2 例は著明改善, 2 例は改 善, 1 例は変化なしで, Stage 2 の 5 例中 2 例は 著明改善， 3 例は改善であった（表 3 )。

自覚症状は重複するものも含め, 最も多かっ たのは咽喉頭異常感で13例であった。続いて嗄 声が 8 例, 胸やけが 5 例, おくびが 3 例, 咽頭 痛・曣下痛が 2 例であった。治療後の自覚症状 
表 4 自覚症状の変化

\begin{tabular}{|c|c|c|c|}
\hline & \multirow{2}{*}{ 治療前 } & \multicolumn{2}{|c|}{ 治 療 後 } \\
\hline & & 改 善(\%) & 変化なし(\%) \\
\hline 咽喉頭異常感 & 13例 & 11例 (84.6) & 2 例(15.4) \\
\hline 嗄 声 & 8 例 & 1 例 (12.5) & 7 例 (87.5) \\
\hline 胸やけ & 5 例 & 4 例 $(80)$ & 1 例 $\quad(20)$ \\
\hline おくび & 3 例 & 3 例 (100) & 0 例 $\quad(0)$ \\
\hline 咽頭痛, 䟞下痛 & 2 例 & 2 例 (100) & 0 例 (0) \\
\hline
\end{tabular}

表 5 下咽頭喉頭所見の変化

\begin{tabular}{|c|c|c|c|}
\hline & \multirow{2}{*}{ 治療前 } & \multicolumn{2}{|c|}{ 治 療 後 } \\
\hline & & 善(\%) & 変化なし(\%) \\
\hline 梨状窩唾液貯留 & 13例 & 11例 (84.6) & 2 例 (15.4) \\
\hline 披裂部の発赤 & 8 例 & 5 例 (62.5) & 3 例 (37.5) \\
\hline 声帯の発赤 & 5 例 & 1 例 (20) & 4 例 (80) \\
\hline 肉芽腫 & 1 例 & 0 例 (0) & 1 例 (100) \\
\hline 声帯結節 & 1 例 & 1 例 (100) & 0 例 (0) \\
\hline
\end{tabular}

表 6 下咽頭喉頭所見と自覚症状との関連

\begin{tabular}{ll|c|c|c|c|c}
\hline & & $\begin{array}{c}\text { 咽喉頭異常感 } \\
(13 \text { 例 })\end{array}$ & $\begin{array}{c}\text { 嗄 声 } \\
(8 \text { 例 })\end{array}$ & $\begin{array}{c}\text { 胸やけ } \\
(5 \text { 例 })\end{array}$ & $\begin{array}{c}\text { おくび } \\
(3 \text { 例 })\end{array}$ & $\begin{array}{c}\text { 咽頭痛, 噮下痛 } \\
(2 \text { 例 })\end{array}$ \\
\hline 梨状窩喠液眝留 & $(13$ 例 $)$ & 8 例 & 7 例 & 1 例 & 1 例 & 2 例 \\
披裂部の発赤 & $(8$ 例 $)$ & 5 例 & 2 例 & 4 例 & 2 例 & \\
声帯の発赤 & $(5$ 例 $)$ & 3 例 & 3 例 & 2 例 & 1 例 & 1 例 \\
肉芽腫 & $(1$ 例 $)$ & 1 例 & & & & \\
声帯結節 & $(1$ 例 $)$ & 1 例 & & & & \\
\hline
\end{tabular}

は咽喉頭異常感で11例, 胸やけで 4 例, おくび で 3 例, 咽頭痛・嶼下痛で 2 例に改善がみられ た。嗄声はわずか 1 例しか改善しなかった。逆 に食道炎の所見を認めた症例中で最も多かった 自覚症状は咽喉頭異常感, 嗄声でそれぞれ 4 例 ずつであった。咽頭痛・矌下痛，おくびが 2 例 ずつで, 胸やけが 1 例であった。おくび, 胸や けはいずれも Stage 2 だけに認められた（表 $4)$ 。

下咽頭, 喉頭所見で最も多かったのは下咽頭 梨状窩の唾液の貯留で13例であった。つづいて 披裂部の発赤が 8 例, 声帯の発赤が 5 例, 声帯 結節が 1 例, 下咽頭に肉芽腫を認めた症例が 1 例であった。治療後における下咽頭，喉頭所見 の軽減, 消失を改善としたところ, 下咽頭の唾 液の貯留で11例, 披裂部の発赤で 5 例, 声帯の 発赤で 1 例, 結節で 1 例の改善を示し, 下咽頭 の肉芽腫は消失しなかった。ここにあげた結節 とは声帯結節の前段階と考えられる発声時の粘 液の foaming のことを示し, foaming の消失を 改善として扱った。

食道炎の所見を認めた症例中最も多かった下 咽頭, 喉頭所見は, 下咽頭梨状窩の唾液の貯留 で 7 例であった。続いて披裂部の発赤が 5 例で, 声帯の発赤, 声帯結節がそれぞれ 1 例ずつであ
った（表 5 )。

\section{IV . 代表的症例}

次に下咽頭喉頭所見と自覚症状との関連を比 較した(表 6 )。かつこ内は下咽頭喉頭所見およ び自覚症状の重複を含めたそれぞれの症例数で ある。梨状窩に唾液の貯留を認める13例中, 咽 喉頭異常感は 8 例, 嗄声は 7 例と半数を超え, 胸やけやおくびは 1 例ずつと少なかった。また 咽頭痛，㺞下痛を訴えた症例は 2 例とも唾液貯 留を認めた。披裂部の発赤を認めた症例は，唾 液の貯留を認めた症例に比較して胸やけやおく びを訴える傾向にあるといえる。

また下咽頭喉頭所見および自覚症状と逆流性 食道炎の関連性についてそれぞれ多変量解析, Fisher 法などの検定を試みたが，今回の症例か らは関連性があるとはいえなかった。

症例 1

患 者: 31歳, 男性

主 訴：咽喉頭異常感，胸やけおくび

嗜好品: 煙草15本/日，コーヒー 3 杯/日，ビ ール 2 本/日

既往歴：特記事項なし

現病歴：1年 6 力月前より症状を訴えていた が放置。しかし，症状が完全に消失しないため 
1994年 5 月17日初診となる。初診時の下咽頭, 喉頭所見は披裂部の発赤のみであったが, 食道 内視鏡所見は Stage 2 の所見を認めた。その後, 外来における生活指導およびプロトンポンプ阻 害剂内服による治療を開始した。治療開始後 10 週目の食道内視鏡所見は Stage 1 に改善されて おり，下咽頭，喉頭所見においても披裂部の発 赤は消失していた。自覚症状も咽喉頭異常感， おくびは消失し，ごく軽度の胸やけを残すのみ となった。

\section{症例 2}

患 者：58歳, 男性

主 訴: 咽喉頭異常感

嗜好品：コーヒー 3 杯/日，ビール 1 缶 (350 $\mathrm{ml}$ )/日

既往歴：特記事項なし

現病歴：1994年 6 月初旬より咽喉頭異常感が 出現したため初診となる。初診時の下咽頭, 喉 頭所見は梨状窩の唾液の貯留で，食道内視鏡で は下部食道の 6 時方向に長軸方向に長い発赤し た浅い楩凹を認め, Stage 1 と分類された。その 後, 外来における生活指導およびプロトンポン プ阻害剤内服による治療を開始した。生活指導 に対して患者は飲酒とコーヒーの制限を行っ た。治療開始後 8 週目に食道内視鏡検査を施行 したところ下部食道の発赤は改善し, 下咽頭, 喉頭所見においても梨状窩の唾液の貯留はほほ 消失していたが, 症状の完全消失には至らなか った。このため食道内視鏡分類は Stage 0 とし た。治療前後で比較した食道内視鏡所見と下咽 頭，喉頭所見を図に示す (図 1，2)。

\section{V. 考 察}

胃内容の食道内への逆流によって起こる食道 粘膜の炎症ないし潰瘍は逆流性食道炎と呼ばれ ているが, この逆流性食道炎の発生には下部食 道括約筋圧の低下, 胃内容と食道粘膜との接触 時間の延長, 逆流した酸性物を胃内に排出する 酸クリアランスの低下などが関与していると言 われている2。現在欧米において逆流性食道炎 は胃食道逆流症 (GERD) の 1 つの疾患として扱 われるようになってきている。

1962年 Kennedy は, 慢性気管支炎の症例を 通し胃食道逆流現象と肺疾患の関連を示唆して
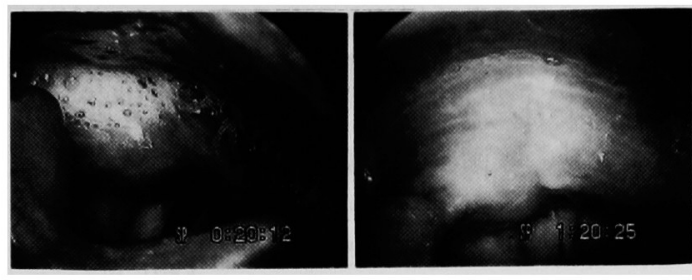

図 1 下咽頭喉頭所見 (左・治療前, 右：治療後)

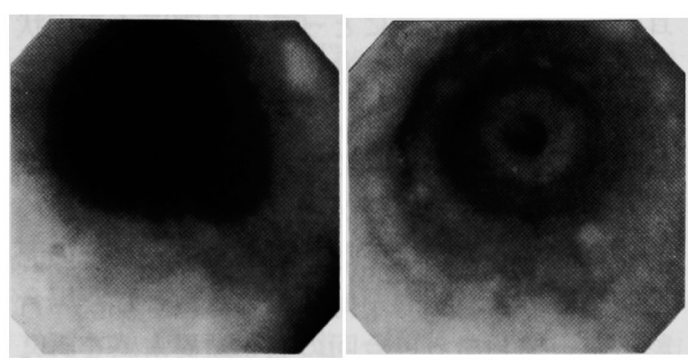

図 2 食道鏡所見（左：治療前，右：治療後）

以来, 胃食道逆流現象は上部消化管および呼吸 器の炎症性疾患や腫瘍性疾患の重要な病因の 1 つとして考えられるようになっだ”。1968年に は Cherry と Margulies が胃食道逆流現象が喉 頭疾患の病因となり得ると初めて提唱し4), 同 年 Delahunty と Cherry はイヌを使用した動物 実験を行い, 胃液を毎日声帯に塗布したものと, イヌの唾液を塗布したものとを比較したとこ ろ, 胃液を塗布していた声帯に肉芽腫が出現し たことを報告した5!。その後, 耳鼻咽喉科領域で も逆流現象が多くの症状を引き起こすことが報 告されるようになった。

\section{1 . 逆流性食道炎の診断について}

逆流現象と関連している症状としては胸や け, おくび, 誤嚥, 嚥下困難, 嗄声, 咽喉頭異 常感, 耳痛, 慢性咳嗽, 喉頭痙攣など非常に多

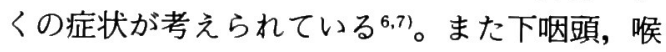
頭所見においても，披裂部の発赤および浮腫, 喉頭後方の炎症, 下咽頭梨状窩の唾液の貯留, 喉頭の接触性潰湟, 肉芽腫などが逆流に関連し ているといわれている7)。今回われわれが経験 した症例中にも同様の症状, 所見が認められた。 今回の 20 症例において下咽頭喉頭所見, 自覚症 状, 食道所見の関連性を統計的に検定し有意な 結果は得られなかったが, 今後さらに症例を増 やし検討が必要であると考えられた。 
これらの所見は逆流した胃内容による直接刺 激で起こる場合と，咳嗽反射などを誘発し，間 接的または二次的に起こる場合とが考えられ る。また，喉頭癌の危険因子として，喫煙と飲 酒が以前より言われているが，いずれも逆流現 象を増加させる因子とされ, 逆流現象が上部消 化管領域の癌発生における危険因子の 1 つとい う可能性も考えられている ${ }^{8,91}$ 。咽喉頭異常感は 耳鼻咽喉科の臨床医にとってよく遭遇する症状 であるが, 器質的病変が認められるものと異常 所見の認められないものとに区別される。後者 は咽喉頭異常感症として扱われ, 積極的な治療 の対象になりにくいのが現状である。

器質的なものでは下咽頭癌や食道癌などの悪 性疾患もあり, 咽喉頭異常感を主訴とした場合 診断が重要となる。今回の咽喉頭異常感を訴え た 13 例中に 4 例の食道炎を認めたが, 各症例の 下咽頭, 喉頭所見としてはごく軽度のものであ った。しかし,これらの症状は逆流性食道炎や 逆流現象だけに認められる症状ではないため, 前述の症状や下咽頭, 喉頭所見が認められた場 合，逆流性食道炎も念頭において他疾患との鑑 別のためにも食道内視鏡検査などが必要と思わ れる。

臨床的に逆流性食道炎を診断するのは困難な ことではなく，24時間 $\mathrm{pH}$ モニタリングや食道 内圧などによる逆流の有無の確認をしなくても 内視鏡的に食道粘膜を観察することが一般的で あり最も重要なものである。しかし, 逆流が軽 度の場合には胸やけや吞酸などの症状があって も, 現時点では内視鏡的に炎症が確認できない 場合もある。このような症例に対しても逆流性 食道炎に準ずる治療を行うことで症状の軽快を みることが多いといわれている10)。われわれが 経験した症例でも, 半数に食道内視鏡的には所 見が認められないが，おくび，胸やけだけでな く咽喉頭異常感, 嗄声など多彩な症状を認めた ため, Stage 0 を食道内視鏡分類に追加した。

耳鼻咽喉科領域では, 咽喉頭異常感に対して 下咽頭食道造影が一般に施行されているが，ア カラシアや狭窄, 顋室などの形態的異常に対し ては有効であるが, 造影検査だけで逆流性食道 炎を診断するのは困難である。

\section{2 . 逆流性食道炎の治療について}

逆流現象に対する治療の第 1 歩は生活習慣の 改善が重要とされている。軽症の患者では日常 生活様式の改善により逆流の抑制, 食道内容排 出の促進が可能で効果が認められており, 今回 の検討においても軽症例が多かったため食事指 導を中心に生活指導を行った。特に夜間は唾液 による酸の緩衝作用や嚥下運動が低下するた め, 逆流に対して咽頭, 喉頭は無抵抗状態にな り, 夜間の逆流の予防が重要な課題となってく る ${ }^{11-13)}$ 。そのため睡眠時に15〜25 cm 程度頭部 を挙上すること, 就寝前 4 時間以内の食事制限

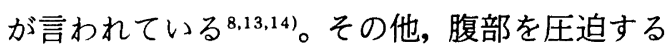
ような服装, 喫煙, 体重の増加などを避けるこ とも生活指導の項目にあげられている。食後に 歌を歌ったり, 重いものを持ち上げたりするこ となども腹圧がかかるため避けるべきである。

食品についても，下部食道括約筋を低下させ る物として脂肪分の多い食事, 炭酸飲料, チョ コレート, 牛乳, 乳製品, 酒類, コーヒーなど, また胃分泌を刺激するものとして柑虂類飲料, 香辛料などがあり，摂取制限の項目にあげられ ている2)。薬剤の影響としては，下部食道括約筋 圧を低下させる物としてカルシウム拮抗剤, テ オフィリン，プロゲステロン，ジアゼパム，モ ルヒネ, 抗コリン剂, $\alpha$ 拮抗剤, $\beta$ 拮抗剤, ドー パミンなどがあり, 合併症治療薬として注意を はらわなくてはならない2,10,13)。

前述した項目に対する生活指導として, 欧米 の耳鼻咽喉科外来では必ずパンフレットの配布 やポスターの掲示がされ，一般患者に対して啓 蒙が行われている。

逆流性食道炎に対する薬物療法は, 消化管運 動機能改善剂, 制酸剂, $\mathrm{H}_{2}$ 受容体拮抗剤, プロ トンポンプ阻害剤などが用いられている。消化 管運動機能改善剂は酸クリアランスの改善, 下 部食道括約筋圧の上昇, 胃内容の早期排出を, 制酸剂は胃内容の中和を, そして $\mathrm{H}_{2}$ 受容体拮 抗剤およびプロトンポンプ阻害剤は胃内の酸分 泌抑制をそれぞれ目的としている15)。

酸分泌の抑制を目的とした治療は，食道内に 逆流する内容の酸度を低下させるのに最も効果 的な方法である。酸分泌抑制剤のうち $\mathrm{H}_{2}$ 受容 体拮抗剤は昼間の酸分泌抑制が弱いという性質 
を持っているが, それに対してプロトンポンプ 阻害剂は昼夜を問わず酸分泌を抑制する ${ }^{16,17)}$ 。 このためプロトンポンプ阻害剤は $\mathrm{H}_{2}$ 受容体拮 抗剤よりも臨床成績が良く, 優れた効果を示し ている。プロトンポンプ阻害剤の投与期間は最 高 8 週間とされているが, 今回得られた結果か らも分かるように十分な効果が期待される。

しかし, 著しい潰瘍形成や強い狭窄, またへ ルニアを合併したり, 肺合併症を伴う症例に対 しては,薬物療法では十分に対応できないため, 噴門形成術や狭窄部の切除などの手術療法が必 要となる。

\section{VI. まとめ}

咽喉頭異常感をはじめ音声障害などを訴え， さらに下咽頭梨状窩に唾液の貯留, 披裂部の発 赤, 声帯の発赤など, 下咽頭, 喉頭に所見のあ る症例には, 腫瘍性疾患を始めその他の鑑別疾 患を念頭に入れ, 逆流性食道炎の可能性も考え, 食道内視鏡の施行を強調したい。また逆流性食 道炎と主訴, 下咽頭, 喉頭所見との関連が考え られる場合, 生活指導とプロトンポンプ阻害剤 の投与も検討するべきである。

\section{文献}

1）小林世美：逆流性食道炎. 現代医学，40：123$126,1992$.

2 ) 本郷道夫，上野正道：逆流性食道炎治療の諸問 題. Modern Physician, 13：1404-1406, 1993.

3 ) Kennedy, J.H. : Silent gastroesophageal reflux. Dis. Chest, 42:42-45, 1962.

4 ) Cherry, J., and Margulies, S.I. : Contact ulcer of the larynx. Laryngoscope, $78: 1937-1940$, 1968.

5 ) Delahunty, J.E., and Cerry, J. : Experimentally produced vocal cord granulomas. Laryngoscope, 78: 1941-1947, 1968.
6 ) Goldberg, M., Noyek, A.M., and Pritzker, K. P.H. : Laryngeal granuloma secondary to gastroesophageal reflux. Otolaryngology, 7 : 196-202, 1978.

7 ) Bain, W.M., Harrington, J.W., Thomas, L.E., et al. : Head and neck manifestations of gastroesophageal reflux. Laryngoscope, 93 : 175179, 1983.

8 ) Olson, N.R.: The problem of gastroesophageal reflux. Otolaryngol. Clin. North Am., 19:119-133, 1986.

9 ) Koufman, J.M. : The otolaryngologic manifestation of gastroesophageal reflux disease (GERD) : A clinical investigation of 225 patients using ambulatory 24-hour $\mathrm{pH}$ monitoring and an experimental investigation of the role of acid and pepsin in the development of laryngeal injury. Laryngoscope, 101:1-78, 1991.

10）本郷道夫, 上野正道：逆流性食道炎の診断と治 療. Pharma Medica, 11：103-109, 1993.

11) Mcnally, M.P.R., Maydonovitch, C.L., Prosek, R.A., et al. : Evaluation of gastroesophageal reflux as a cause of idiopatinic hoarsness. Digestive Dis. Sci., 34 : 1900-1904, 1989.

12) Orr, W.C., Robinson, M.G., and Johnson, L. F. : Acid clearance during sleep in the pathogenesis of reflux esophagitis. Digestive Dis. Sci., $26: 423-427,1981$.

13) Sataloff, R.T. : Professional Voice, The Science and Art of Clinical Care, pp.179-183, Raven Press, Ltd., New York, 1991.

14) Murphy, D.W., and Castell, D.O. : Path. ogenesis and treatment of gastroesophageal reflux disease. Resident \& Staff Physician, $33: 37-45,1987$.

15）関口利和, 堀越 勤：逆流性食道炎の治療のあ り方. 消化器内科, $16 ： 367-374,1992$.

16）本郷道夫, 上野正道：逆流性食道炎. 実験治療, $635: 40-43,1994$.

17）岸 清一郎, 伊東 進, 梶本宜史 -他：逆流性 食道炎に対する lansoprazole の臨床的有用性 の検討. Prog. Med., 10：322-331, 1990. 